\title{
ЭКСПЕРИМЕНТАЛЬНОЕ СОПЛО ДЛЯ ОЧИСТКИ СЕЛЬСКОХОЗЯЙСТВЕННОЙ ТЕХНИКИ В АПК
}

Сергей Эдуардович Блинов аспирант

\author{
Александр Владимирович Шемякин \\ доктор техн. наук, доцент \\ ФГБОУ ВО «Рязанский государственный \\ агротехнологический университет имени П.А. Костычева»
}

Аннотация: Серьезной проблемой сельскохозяйственного производства сегодня является простой транспортно-технологических сельскохозяйственных машин. Частой причиной разрушений элементов техники, которые ведут к простою, являются грязевые отложения, которые агрессивно воздействуют на структуру и свойства узлов и деталей. Это диктует необходимость разработки эффективных механизмов очистки техники.

Ключевые слова: пневмоабразивные установки, очистка, сельскохозяйственная техника, транспортно-технологические машины, сопло, абразивы.

\section{EXPERIMENTAL NOZZLE FOR CLEANING AGRICULTURAL MACHINERY IN THE AGRO-INDUSTRIAL COMPLEX}

Sergej E. Blinov Aleksandr V. Shemyakin

\begin{abstract}
A serious problem of agricultural production today is the downtime of transport and technological agricultural machinery. Frequent cause of machinery elements failure, which leads to downtime, is mud deposits, which aggressively affect the structure and properties of units and parts. This dictates the need to develop effective mechanisms for cleaning machinery.

Key words: pneumatic abrasive installations, cleaning, agricultural machinery, transport-technological machines, nozzle, abrasives.

\section{Введение.}

Перспективным направлением повышения качества механической очистки металлических конструкций является струйная пневмоабразивная обработка машин, механизмов и их элементов, и составных частей, которая
\end{abstract}


также может быть использована при очистке сельскохозяйственной техники от коррозии, застарелых лакокрасочных покрытий и загрязнений при подготовке к длительному хранению.

Учитывается, что твёрдость частиц отходов зерна ниже твёрдости нанесённой защитной поверхности техники, но выше твёрдости загрязнения.

Однако применение стандартных сопел с таким абразивом затруднительно, т.к. вследствие своей структуры, отходы зерна закупорят отверстия устройства и прервут процесс очистки.

\section{Описание.}

Для повышения эффективности применяемых в РФ абразивоструйных очистительных устройств [1] для снятия застарелых лакокрасочных покрытий, грязевых отложений и коррозионного слоя [2 с. 169; 3 с.137-139] с частей, и элементов сельскохозяйственной техники и оборудования, транспортнотехнологических машин [4 с.279-282; 5 с. 36-44; 6 с. 20-24], разработано специализированное конструктивное приспособление. Разработанная модель представляет собой экспериментальное сопло. На рис. 1 представлено устройство разработанного экспериментального сопла, составленная авторами.
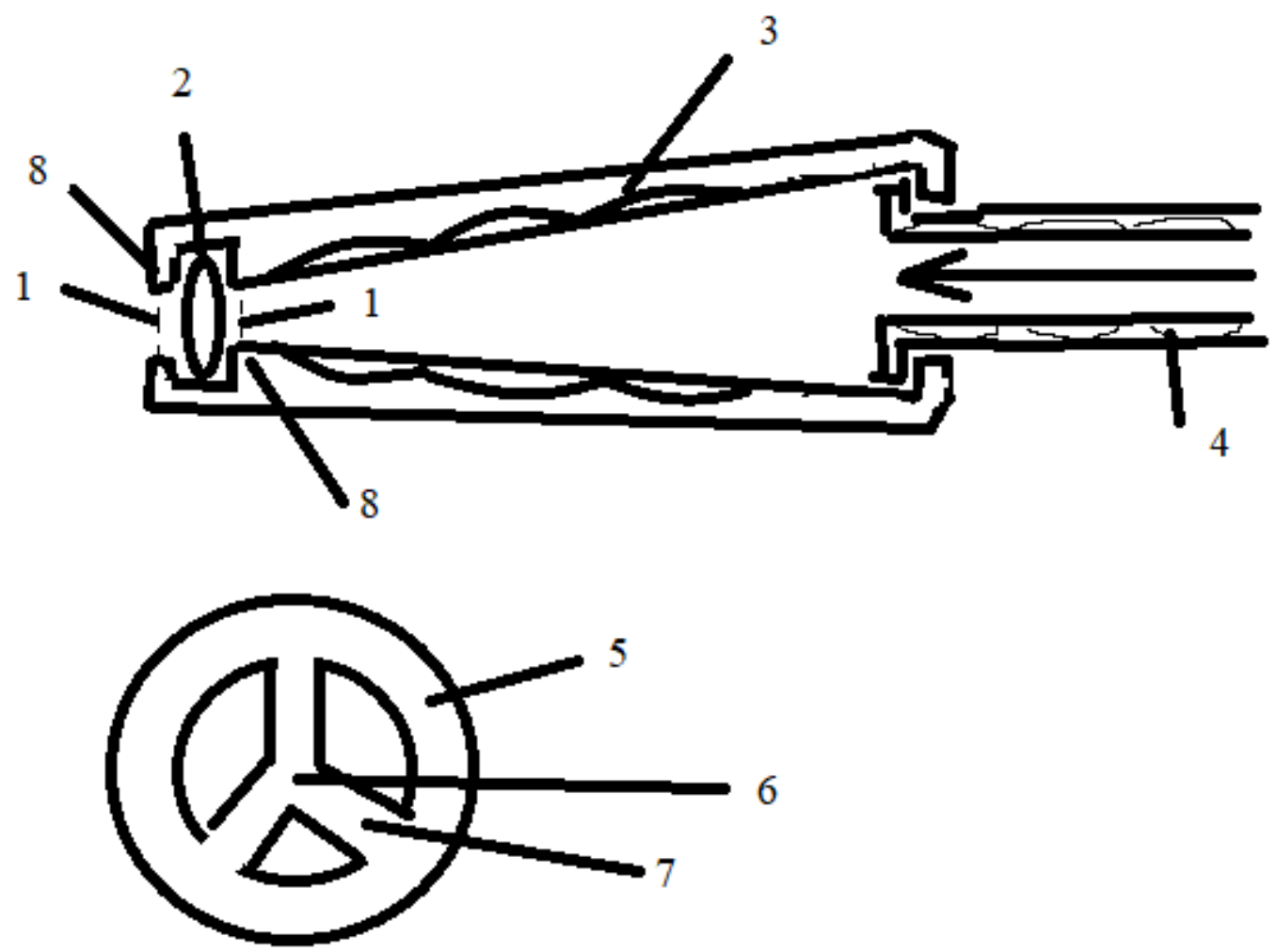

Рис. 1. Устройство экспериментального сопла: 1 - защитная сетка;

2 - рассекатель; 3 - корпус сопла с внутренней радиальной нарезкой (бороздками); 4 - шланг с внутренней радиальной нарезкой; 5 - борт опоры рассекателя; 6 - выпуклый центр рассекателя; 7 - ребро лопасти; 8 - буртик 
Принцип работы сопла основан на разбивании струи воздуха с добавленным абразивом на части и стабилизации движения частиц абразива неправильной формы. Для этого применяется не закреплённый лопастной рассекатель (2), закреплённый на конце сопла буртиками (8) с двух сторон. Благодаря форме рассекателя - поток воздуха раскручивает его. В результате струя, проходя через рассекатель, разделяется на 3 части. Каждая лопасть имеет ребро (7), увеличивающееся от края лопасти к центру, благодаря чему поток разбивается, но не теряет силы. Возможный материал изготовления рассекателя - пластик. Также к буртикам (8) прикреплены мелкие металлические защитные сетки (1), которые не дают рассекателю залечь на буртиках (8). Также внутри сопла имеется радиальная внутренняя нарезка (3), которая увеличивает пропускную способность и стабилизирует движение частиц абразива. Возможный материал изготовления корпуса сопла - пластик или керамика. Совместно с соплом предполагается использовать шланг (4) или трубку с такой же радиальной внутренней нарезкой. Нарезка выполняется с помощью дорна резца для продольной нарезки каналов внутри.

Дорнирование выполняется посредством ударного воздействия небольшого молотка по дорну [7]. Размер дорна выбирают по диаметру трубы или шланга.

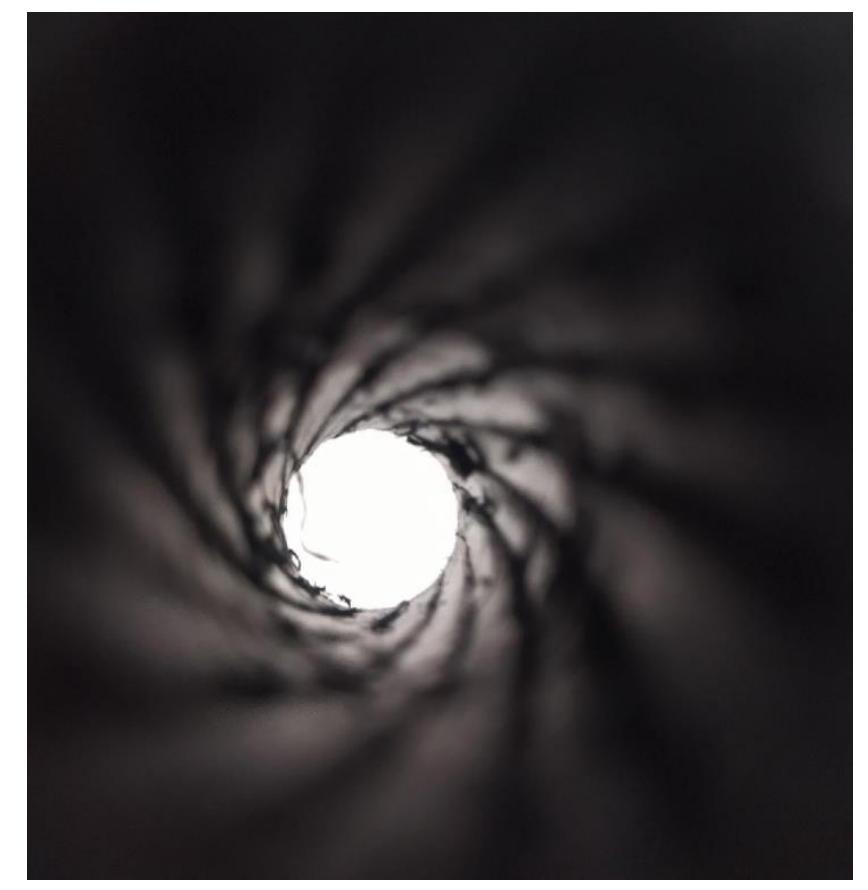

Рис. 2. Изображение шланга изнутри после дорнирования

\section{Заключение.}

В результате слой, который подвергается удалению повреждается в результате ударного воздействия частиц отходов зерна, а сжатый воздух, в 
свою очередь, отрывает повреждённый слой от поверхности [8].

Благодаря применению абразивоструйных технологий снижается трудоёмкость процесса и обеспечивается эффективный процесс очистки.

\section{Список литературы}

1. ГОСТ 24055-2016 Техника сельскохозяйственная. Методы эксплуатационно-технологической оценки (Переиздание). Введ. 2018-01-01. М.: Стандартинформ, 2020.

2. Астахова Е.М. Повышение эффективности подготовки сельскохозяйственных машин к хранению средствами машиннотехнологических станций с разработкой методики оценки качества: дис. ... канд. тех. наук: 05.20.03 / Астахова Елена Михайловна. Рязань, 2007. 169 с.

3. Шемякин А.В. Детерминальная модель хранения сельскохозяйственной техники // Всб.: Научное наследие профессора П.А. Костычева в теории и практике современной аграрной науки. Материалы Всероссийской научнопрактической конференции. - Рязань, 2005. - С. 137-139.

4. Киселев В.А., Шемякин А.В. Совершенствование процесса очистки техники от загрязнений. // Всб.: МОЛОДЕЖЬ И XXI ВЕК. Материалы IX Международной молодежной научной конференции. - Курск, 2019. C. 279-282.

5. Блинов С.Э., Шемякин А.В. Применение природоподобных технологий для очистки сельскохозяйственной техники в АПК. // Международный техникоэкономический журнал. - 2021. - № 3. - С. 36-44.

6. Арефьев В.А., Блинов С.Э., Шемякин А.В. Повышение качества очистки сельскохозяйственных машин от загрязнений // Приоритетные направления инновационного развития транспортных систем и инженерных сооружений в АПК: Материалы международной студенческой научнопрактической конференции, Рязань, 17 февраля 2021 года. - Рязань: Рязанский государственный агротехнологический университет им. П.А. Костычева, 2021. - C. 20-24.

7. Толмачев, В.С., Терешин А.В. Изменение конструкции дорна, дорнового устройства и профиля бойка валков пилигримового стана на Северском трубном заводе // Металлург. - 2009. - № 6. - С. 59-60.

8. Санитарно-эпидемиологические правила СП 2.2.2.1327-03: Гигиенические требования к организации технологических процессов, производственному оборудованию и рабочему инструменту. 